\title{
Do Buyer's Supporting Efforts For Sub-Supplier Make Prime Supplier's Performance Better?
}

Kyunghee Kim, Sungkyunkwan University, South Korea

Minhye Park, Sungkyunkwan University, South Korea

Sungmin Ryu, Sungkyunkwan University, South Korea

\begin{abstract}
It is widely accepted that capable suppliers do important role for buyer's competitiveness in today's business environment. Moreover, not only the importance of supplier development but also the importance of sub-supplier development has been emphasized. This study examines how buyer's efforts of supporting sub-supplier development impacts on performance of prime supplier. The study results show that while buyer's effort of monitoring and information sharing to sub-suppliers improve the performance of prime supplier, buyer's effort of knowledge sharing do not improve prime supplier's performance.
\end{abstract}

Keywords: Knowledge Sharing; Information Sharing; Monitoring; Supplier

\section{INTRODUCTION}

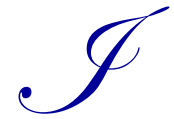

$\mathrm{t}$ is widely accepted that in order to compete and survive, firms must seek, build up and maintain relationships with capable suppliers and extract the maximum value through such relationships (Dyer, 1996; Wanger, 2005). In accordance with this, supplier development issues caught attention of researchers in supply chain management filed. However, in recent years, more firms gradually concern on the root of their supply chains. For example, according to a 2012 news article, Starbucks and Nestlé have stepped ups assistance to farmers to secure stable supply. This included financial, technical and infrastructure aid (Lucas, 2012). Yet, there is no much research questioning and testing empirically whether the involvement of buying firms in the development of sub-suppliers will make any difference.

Today, along with the spontaneous assistance to sub-suppliers, social pressures gradually force large buying firms to take serious responsibility of directing sub-suppliers' improvement. NGOs put strong pressure on firms to concern even on the supplier's labor working condition. Apple had to agree on the audit of one of its top supplier to reduce work hours (Chao et al., 2012). What people and the government expect is that the buying firms' exertion would obtain effective outcomes that can advance sub-suppliers. Society expects that there must be a difference between buying firms' effort on sub-supplier improvement and prime suppliers' effort on that. Despite the perspective, it is hard to find researches investigating that effect.

Until recent, most supplier development researches have focused on focal dyad relationships as other supply chain researches have done, although triad structure (i.e., buyer - prime supplier - sub-supplier) or four-level structure is much more common in practice. Simplified context allowed researchers to have contributed to the supply chain studies theoretically and practically. Yet such approach does not provide in-depth understanding of the impact of a third party on a relationship between two other organizations (Mena et al., 2013).

This study attempts to examine improvements of sub-suppliers as a result of buying firms' effort in terms of monitoring, knowledge- and information sharing. Further, this study examined how the improvements impact the performance of prime suppliers'. A review of the literature indicates that there is no study which empirically tests the performance of prime suppliers due to buying firms efforts made for sub-suppliers. This research addresses this gap by providing empirical tests and exploring the mechanisms through which it is achieved. 


\section{CONCEPTUAL FRAMEWORK}

\section{Supplier Development}

When a firm found its suppliers lacking in performance, it can approach to the problem in several ways. These approaches are (1) supplier switching, finding alternative supplier and sourcing the product from a more capable supplier, (2) vertical integration, acquiring suppliers to produce product in-house, and (3) supplier development, enhancing the performance of suppliers through supporting the suppliers such as knowledge transfer (Krause, 1999; Wagner, 2006; Jang 2014). The first two options may not be successfully implemented. Searching better alternatives is not always viable and hierarchies require substantial costs which is associated with governance and decision making and which refers to the potential sources of inefficiencies that may be present within a given organizational form (Kapoor \& Lee, 2013). Therefore, the need for supplier development has been suggested by many buying firms and they report that they need a serious need for supplier developments in the areas of quality, cost, delivery, innovation, and product design (Morgan, 1993; Krause et al., 2000).

Buying firms also engage in supplier development when they adopt a strategic perspective toward suppliers (Wagner, 2005; Arroyo-López et al., 2012; Hur et al., 2014). Such perspective changes buying firms' view on the buying firmsupplier relationships. According to a study results, buying firms' perspective on their suppliers is influenced by buying firms' market competitiveness and upper management recognition of the purchasing function (Krause, 1999). As buying firms view their market more competitive and as top management acknowledge the purchasing function more important, the buying firms invest time and resources to improve suppliers. Regarding the performance outcomes of supplier development, De Toni and Nassimbeni (2000) found that better performing plants exhibit a higher use of supplier development (i.e., monitoring, assistance, training, and incentives). In similar vein, Dyer and Hatch (2006) found that automobile suppliers which had been experienced supplier development from Toyota show greater performance outcomes than other suppliers those who were partner of US firms and who were not supported by buying firms. In a recent study, Routroy and Pradhan (2013) defined critical success factors that influence supplier development. Those factors are long-term strategic goal, proximity to manufacturing base, top management commitment, information sharing, environmental readiness, innovation capability, supplier certification, incentives, supplier's supplier condition, direct involvement, and external environment (Ryu et al., 2014; Min et al., 2015).

\section{Sub-Supplier Development}

Previous studies about supplier development focused on the development of suppliers as a whole, meaning that the extant supplier development studies did not indicate that whether the suppliers they examined were prime- or subsuppliers. In this study, the suppliers those whom are subjected to be studied are distinguished.

Our study focuses on the subsupplier development and its impact on the performance of prime supplier. This study defines sub-supplier development as any effort made by a buying firm to improve a sub-supplier's performance and capabilities to lead linear performance improvement in a supply chain. The term "linear performance improvement" refers to the domino-effect like performance improvement in a supply chain in that betterment from the root is prerequisite for successful achievement in a supply chain. A recent survey found that Korean large firms promote their prim suppliers' overseas expansion because they experienced that their product quality gets better through suppliers' performance development and increased global competitiveness (FKILSC, 2014). Same logic can be applied between supplier and sub-supplier. Theoretically, sub-supplier development will positively influence the supplier performance, which in turn to meet the buying firm's supply needs and to increase competitiveness of business network as a whole.

Knowledge sharing to improve sub-suppliers can be regarded as transaction-specific investment for two reasons: (1) because the success of knowledge transferring depends on the acceptability of receivers as well, the knowledge that would be passed has to be modified and customized. This restructured knowledge is a sub-supplier-specific knowledge, meaning that it may not be applicable to others. (2) Knowledge sharing has the relation to the notion of sunk cost. Once transferred to a sub-supplier, it cannot be recovered. The receiver may use the knowledge for other customers. Even more, in a worse case, the relationship between the buying firm and the sub-supplier can be terminated. In such case, the buying firm theoretically pays severance payment. 
Based on the TCE (Transaction Cost Economics) perspective, buyers' activities to improve sub-suppliers' performance correspond to transaction specific investment (Williamson, 1985). These include on-site consultation, education and training programs, temporary personnel transfer, and provision of equipment (Krause, 1997; Krause et al., 2000; Wagner, 2006). Those activities require time, effort, and money that are used for only sub-suppliers that the buying firms want to develop. Once such resources are spent on specific sub-suppliers, it is irreversible and cannot be used in other relationships with other sub-suppliers.

Buying firms are more likely to encounter greater risk when they invest resources in sub-suppliers then when the investment is made for prime suppliers. In the most buyer-prim supplier relationships, the investment can be safeguard by a contract which is associated with such as outsourcing volume. In general, however, buying firms do not establish a direct contract relationship with sub-suppliers, thereby once decided to engage in sub-supplier development, the investments put the buying firms in a vulnerable position. They hardly have a way of recovering the investment when the relationship terminates, and hence get the termination penalty (Williamson, 1996).

Notwithstanding risks that buying firms have to encounter, there is demonstrable justification for buying firms' engagement in sub-supplier development: a firm's ability to create and appropriate value is critically dependent on actors that produce complementary products or services (Dyer \& Nobeoka, 2000; Kapoor \& Lee, 2013). Firm value comes from their ability to provide products that can satisfy consumer tastes.

\section{HYPOTHESES DEVELOPMENT}

\section{Monitoring}

Monitoring is a widely accepted practice at works, recognized as the generic organizational process between buyers and suppliers (Heide et al., 2007; Kim \& Lee, 2016) and as the integral parts of many firms' strategies that ensure value creation (Ghosh and John, 1999; Heide et al., 2007). Despite its crucial role, extant studies reveal somewhat disappointing results about its effectiveness for suppliers. Evaluation of suppliers was found to have no relation supplier's performance and capabilities (Arroyo-López et al., 2012) and monitoring affect performance improvement of suppliers but only indirectly (Krause et al., 2000).

Although extant studies show that monitoring does not directly affect performance of suppliers, the relationship can probably be changed when a subsupplier receives monitoring from its manufacture directly. Unlike prime suppliers which may have self-evaluation system (Krause et al., 2000; Kim et al., 2015), a continuous improvement orientation, and which exhibit superior operational innovativeness (Azadegan, 2011), which shows the ineffectiveness of monitoring system as is expected, sub-supplier may face difference situation.

Sub-supplier may not be able to have such system because that normally requires willingness, knowledge, funds and other various resources to be implemented. For the reasons above why monitoring program is not effective to be reasonable, it must be true that either: (1) firms should not have enough resources to implement such system (e.g., self-evaluation system); (2) firms should not have willingness to do it. If so, manufacturer's monitoring can be effective on sub-suppliers which normally have fewer resources, relatively to prime suppliers, to put on setting such system. Manufacturer's monitoring can provide motivation for better performance of sub-supplier by giving some tips of direction to drive improvement objective (Kruse et al., 2000; Lee et al., 2014; Wang 2015; Rhee \& Cho, 2016; Ko \& Smith, 2016), which will affect prim supplier performance and hence satisfies the manufacturer.

H1. A manufacturer's effort to sub-supplier development through monitoring will increase the performance of prime suppliers.

\section{Knowledge and Information Sharing}

Before conceptualizing information sharing and knowledge sharing, this study characterizes dimensions of knowledge and information based on the attributes based on previous literatures. Scholars divided knowledge into two categories: (1) explicit knowledge or information, which can be easily defined, such as delivery schedule and (2) tacit knowledge 
or know-how, which is difficult to define such as production knowledge (Kogut \& Zander, 1992; Modi \& Mabert, 2007; Kang et al., 2016; Kang \& Smith, 2016).

1. Substantiality: Information has substantive content which helps decision making of what to do. For example, production and delivery schedule of a firm can be described as numbers. Manger of the firm can set a plan of how many pieces of products have to be produced and choice of means of transportation. Knowledge, on the other hand, is not easily codified and is associated how to produce the product and how to solve possible problems during the production. Knowledge, thereby, allows one to do something smoothly and efficiently (Von Hippel, 1988).

2. Transferability: It is partly related to time dimension. Information is easily transmitted to others with small cost. It does not require large amount of time and large sum of money to deliver say a production schedule. Also, information becomes obsolete as time passes, and therefore, needs to be recreated. Transferring knowledge, however, takes time because nobody can deliver all knowledge he has in one single action. It is acquired by 'accumulated' experience (von Hippel, 1988), meaning that it must be learned and it needs time to learn. Unlike information, acquiring knowledge needs learning effort of receivers as well.

3. Replicability: This is partly related to substantiality and codifiability. Because there is no much difficult of creating information, it is easily reproduced at a lower cost (Kogut \& Zander, 1992). Knowledge is much more complex and therefore is not easy to codify the actions that should be implemented. Though each part or step of doing something can be written, there are subtle and delicate situations that cannot be described. Therefore, imitation of knowledge is much more difficult.

\section{Knowledge Sharing}

This study defines knowledge sharing as the activities of transferring knowledge and technological skills from manufacturing firms to their sub-suppliers to improve performance of sub-suppliers. In this setting, knowledge covers wide range of managerial know-how, transferring technology, and providing critical resources.

The importance of knowledge is needless to say in terms of firm competency. A firm's existing knowledge base delimits its scope and capacity to comprehend and apply novel knowledge to radical innovations (Hill \& Rothaermel, 2003; Zhou \& Li, 2012; Wang 2015). Organizations that can make full use of knowledge are likely to be more innovative, efficient, and effective in the market place (Grant 1996; Argote et al., 2000; Cai et al., 2013). Due to such importance, the effects of knowledge sharing on supply chain performance have gained increasing attention in recent years (Malhotra et al., 2005; Cai et al., 2013; Hwang \& Lee, 2016; Jeon \& Ha, 2016). Study results reveal that organizations that are able to transfer knowledge effectively from one unit to another are more productive and more likely to survive than organizations that are less adept at knowledge transfer (Argote et al., 1990; Baum \& Ingram, 1998; Darr et al., 1995).

To the recipient, here the sub-supplier, knowledge sharing from the manufacturer is a way of acquiring competitive advantages because it provides the way of how to produce a product and solving possible problems during the production (Von Hippel, 1988). Therefore, it allows the sub-supplier to achieve organizational effectiveness and efficiencies as well. From the external standard, the sub-supplier can meet the demands of its buyer (Pfeffer and Salancik, 2003: 11), the prime supplier in this study, which desire to increase its product quality that is to be judged by the manufacture. From the internal standard, knowledge contributes to achieving organizational efficiencies because it helps the sub-supplier doing better what it is currently doing (Pfeffer and Salancik, 2003: 11) through such as reducing cost and time to make a product.

Social exchange theory says that when members observe that they receive support from their leaders, they develop an obligation to reciprocate (Gouldner, 1960; Erdogan and Enders, 2007). Manufacturing firm's knowledge sharing with sub-suppliers has higher probability of increasing motivation of sub-supplier to be reciprocating by demonstrating higher performance. Increased performance of sub-supplier tends to lead increased performance prime supplier, hence to satisfy manufacturer. 
H2. The buying firms' effort to sub-supplier development through knowledge sharing will increase the performance of prime suppliers.

\section{Information Sharing}

This study defines information sharing as the activities of transferring or disseminating information from buying firms to their sub-suppliers enabling them to have and occupy same information and to use the information. In this setting, information covers many issues related to operations such as day-to-day operations, customer demand, new item development, marketing planning and so on.

Researchers have shown the importance of information flows in supply chain management. According to their study results, information sharing is crucial in collaborative relationship (Frankel et al., 2002; Min et al., 2005; Lim et al., 2014; Nam et al., 2015; Kasheer, 2015), eases to flow of products, services, funds, and feedback between the partners (Min et al., 2005), and builds innovation capabilities (Soosay et al., 2008), which is in turn vital to the creation of firm capabilities and/or performance outcomes (Min et al., 2005).

This study argues that as manufactures share information with their sub-suppliers, performance of prime-suppliers will be increased. Two rationales could support this argument. The first one is "bullwhip effect", referring to the phenomenon where orders to the supplier tend to have larger variance than sales to the buyer and this effect gets amplified as the number of intermediaries in the channel increases (Forrester, 1961; Sterman, 1989; Lee et al., 2004; Jun et al., 2014; Kim, 2015). The bullwhip effect and related information sharing issues have been mainly recognized and studied in the relationship between retailer and manufacture. However, it is also conceivable that this logic is applicable to upstream supply chain. A sub-supplier could face such difficulty if the supplier was grant to access information only through a prime supplier. This implies that information could be easily distorted as it goes through from the top manufacture to the upstream suppliers. To solve this problem, scholars (Lee et al., 2004) suggest some possible solutions. For quick and easy distribution of information, the manufacture should be granted a right to access to demand data at the retail outlet. Furthermore, they also suggest that performing forecast and order by a single member of supply chain could eliminate such effect. Like this, if the manufacture decides to give information to its sub-supplier directly, the supplier is able to improve production scheduling, inventory control and delivery plans (Lee et al., 2004), which directly related to performance of the sub-supplier itself and therefore improve performance of the prime supplier.

Second, direct information sharing between the manufacturer and the sub-supplier would reduce information uncertainty, meaning the absence of information (Daft et al., 1987; Kydd, 1989; Grover et al., 2006) or information asymmetry which is a result of different interpretations of the same information or access to different information sets (Mishra et al., 2007) between suppliers. A manufacturer's decision to distribute information stage by stage, which means information flows from the manufacturer to a prime supplier and to a sub- supplier, is likely to incur information uncertainty or information asymmetry. To reduce information unavailability, the sub-supplier needs to put additional resources on searching information (search-cost occurs), which would contribute improving performance otherwise. In that sense, such information distribution system could be regarded as a way of reduction in performance by reducing effectiveness and efficiency. In the effectiveness perspective, resources are spent to search information but not to be spent on improving production hence to lose opportunity of creating acceptable outcomes. In the efficiency perspective, performance such as delivery could be improved at same overall cost if it is not used in search information. Therefore, a manufacturer's decision to share information with sub-supplier directly would improve performance of the sub-supplier which in turn improve the prime supplier.

H3. The buying firms' effort to sub-supplier development through information sharing will increase the performance of prime suppliers. 
Figure 1. The Research Model

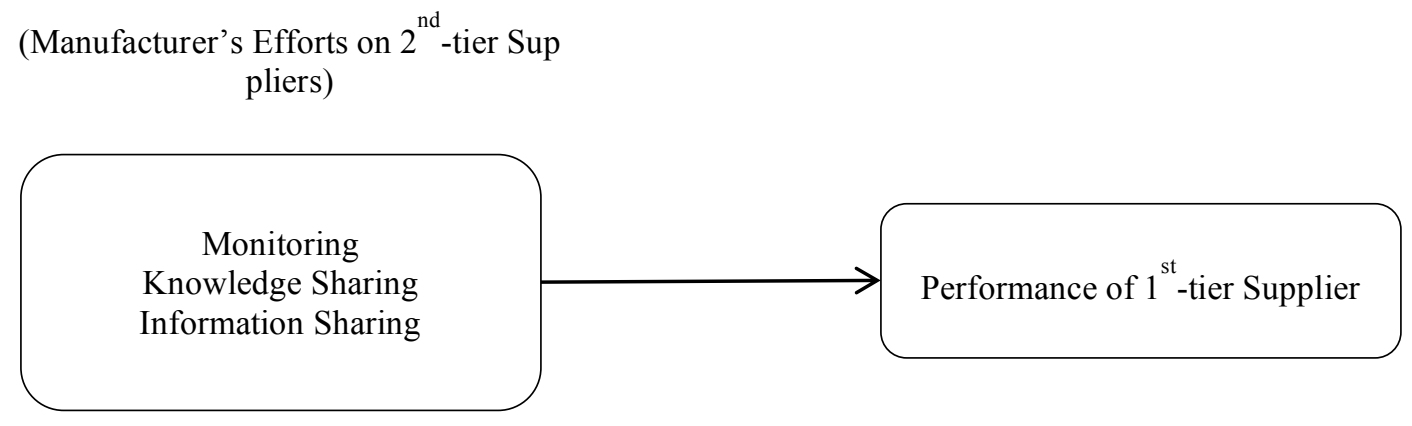

\section{METHODOLOGY}

\section{Sample and Data Collection}

The focus of this study was to examine how buying firms' efforts on the sub-supplier development impact on the performance of prime suppliers. This study defined the prime suppliers as the suppliers which have direct transaction relationships with manufacturing companies and the sub-suppliers as the suppliers which direct transaction relationships with prime suppliers. Therefore, although the manufacturing companies and sub-suppliers do not have direct transaction relationship and hence are not legally bounded in terms of contracts, they have sort of relationships.

To examine the hypotheses, this study considered companies that are listed on KCCP (Korean Commission for Corporate Partnership) which evaluates shared growth between 109 Korean large companies and their suppliers two times every year. The commission regularly sends questionnaires to prime- and sub-suppliers of the 109 companies to investigate and evaluate whether they abide by the agreements and index the degree of shared growth of each firm.

Of the companies, this study chose 79 companies which are engaged in electronics, machinery, construction, automotive, chemical, and shipping industry because of following reasons. First, they are included in the secondary industry and especially manufacturing industries. Manufacturing companies probably have higher motivation of engaging in sub-supplier development than other industries. To these firms, securing technologically qualified prime suppliers can be regarded as the most important factor for competitiveness. And the performance of prime suppliers is definitely based on sub-suppliers. Second, the companies which are excluded from the data collection are mostly engaged in retailing and food industry receiving lower scores for the last consecutive years. And most firms in retailing and food industry barely have relationships with sub-suppliers because the business mostly deals with moving of finished products. So they do not have occasions of involving in the manufacturing process of sub-suppliers.

The author contacted managers working for the 79 companies to introduce this research and persuade them to participate into our study. The managers are in charge of dealing with suppliers. Among them, 35 companies allowed us to send questionnaires. We sent five copies to each company by mail because every firm has many managers who are dealing with a whole raft of suppliers which provide different products. Among 175 questionnaires, 105 were returned $(60 \%)$. Among them, 5 respondents were eliminated because of excessive missing answers. Therefore, a sample of 100 was used for the analysis.

\section{Measure Development}

The author developed the questionnaire from the existing studies. The author reviewed literatures to list the constructs and measures. Then we developed a draft questionnaire and put the items into Korean language. Then we asked two professional translators to re-translate the items into English to check whether the translation conveyed the meanings of the original language. The draft questionnaire was sent to three managers who the author talked with to review all the questions whether the questions are readily understandable. The managers sent back us the questionnaires with some feedbacks of modifying. Following some revisions, the author sent the questionnaire to managers who agreed with completion of the questionnaire. 
This research constructs reflect the perspective manufacturers. The questions asked to some degree the manufacturers are making effort for their sub-suppliers in terms of monitoring, knowledge sharing, and information sharing, and the influence of the efforts on the performance of prime suppliers. The performance of prime suppliers is measured with the perceived satisfaction of the manufacturers. It reflects how the manufacturers are satisfied with the product quality, service, on-time delivery and overall supply situation. Table 1 show the constructs used in our research model.

Table 1. Constructs Measures

\begin{tabular}{|c|c|c|c|}
\hline Construct & Item & $\begin{array}{c}\text { Description } \\
\end{array}$ & References \\
\hline \multirow{4}{*}{ Monitoring } & MO1 & We closely monitor supply situation of sub-supplier & \multirow{4}{*}{$\begin{array}{l}\text { Adapted from } \\
\text { Stump, Rodney } \\
\text { and Jan Heide } \\
\text { (1996) }\end{array}$} \\
\hline & MO2 & We carefully evaluate product quality of sub-supplier & \\
\hline & MO3 & We regularly monitor delivery accuracy of sub-supplier & \\
\hline & MO4 & We use evaluation program in relation to supply of sub-supplier & \\
\hline \multirow{4}{*}{$\begin{array}{l}\text { Knowledge } \\
\text { Sharing }\end{array}$} & KS1 & We share engineering capability with the sub-supplier & \multirow{4}{*}{$\begin{array}{l}\text { Adapted from } \\
\text { Cai et al., (2013) }\end{array}$} \\
\hline & KS2 & We are transferring technologies to the sub-supplier & \\
\hline & KS3 & We are providing marketing know-how to the sub-supplier & \\
\hline & KS4 & We are willing to share key resources with the sub-supplier & \\
\hline \multirow{4}{*}{$\begin{array}{l}\text { Information } \\
\text { Sharing }\end{array}$} & IS1 & We provide any information that might help the sub-supplier & \multirow{4}{*}{$\begin{array}{l}\text { Adapted from } \\
\text { Heide \& Miner } \\
\text { (1992) }\end{array}$} \\
\hline & IS2 & We provide information to the sub-supplier frequently and informally & \\
\hline & IS3 & We provide same information to the prime supplier and sub-supplier & \\
\hline & IS4 & We keep the sub-supplier informed about events or changes that may affect them & \\
\hline \multirow{4}{*}{ Performance } & PE1 & We are satisfied with prime supplier's product quality & \multirow{4}{*}{$\begin{array}{l}\text { Adapted from } \\
\text { Ryu \& } \\
\text { Eyuboglu } \\
(2007)\end{array}$} \\
\hline & PE2 & The service provided by prime supplier is satisfactory & \\
\hline & PE3 & We are satisfied with the overall supplying of prime supplier & \\
\hline & PE4 & We are satisfied with the on-time delivery performance of prime supplier & \\
\hline
\end{tabular}

* $1=$ strong, $7=$ weak

\section{Confirmatory Factor Analysis}

This study conducted the CFA analysis by using SEM to assess construct validity (Grewal et al., 2010). The model fit was follows:

Table 2. Factor Analysis

\begin{tabular}{|c|c|c|c|c|c|c|}
\hline Construct & Item & $\begin{array}{c}\text { Standardized } \\
\text { Factor Loading }\end{array}$ & t-value & AVE & Mean & SD \\
\hline \multirow{4}{*}{ Monitoring } & MO1 & .838 & 8.94 & \multirow{4}{*}{.72} & \multirow{4}{*}{3.56} & \multirow{4}{*}{1.00} \\
\hline & $\mathrm{MO} 2$ & .916 & 9.90 & & & \\
\hline & MO3 & .859 & 9.21 & & & \\
\hline & MO4 & .768 & 8.94 & & & \\
\hline \multirow{4}{*}{$\begin{array}{l}\text { Knowledge } \\
\text { Sharing }\end{array}$} & KS1 & .834 & 10.17 & \multirow{4}{*}{.71} & \multirow{4}{*}{3.57} & \multirow{4}{*}{0.83} \\
\hline & $\mathrm{KS} 2$ & .845 & 10.38 & & & \\
\hline & KS3 & .850 & 10.48 & & & \\
\hline & $\mathrm{KS} 4$ & .851 & 10.17 & & & \\
\hline \multirow{4}{*}{$\begin{array}{l}\text { Information } \\
\text { Sharing }\end{array}$} & IS1 & .712 & 7.60 & \multirow{4}{*}{.61} & \multirow{4}{*}{3.45} & \multirow{4}{*}{0.75} \\
\hline & IS2 & .751 & 8.14 & & & \\
\hline & IS3 & .823 & 9.12 & & & \\
\hline & IS4 & .835 & 7.60 & & & \\
\hline \multirow{4}{*}{ Performance } & PE1 & .868 & 13.29 & \multirow{4}{*}{.80} & \multirow{4}{*}{3.36} & \multirow{4}{*}{0.96} \\
\hline & PE2 & .854 & 11.47 & & & \\
\hline & PE3 & .927 & 13.51 & & & \\
\hline & PE4 & .920 & 13.29 & & & \\
\hline
\end{tabular}

Discriminant validity is assed using AVE. When the square root of the AVE of each construct should be much larger than the correlation of the specific construct with any of the other construct, then the discriminant validity is satisfied with the rule (Fornell \& Larcker, 1981). As can be seen from Table 3, the value of $\mathrm{r} 2$ between all constructs is between 
$0.2 \sim 0.34$, which is smaller than the lowest AVE value of Information Sharing, 0.61 . Therefore, all constructs in this study have discriminant validity.

Table 3. Discriminant Validity

\begin{tabular}{|c|c|c|c|c|}
\hline Construct & AVE & $\mathbf{r}$ & r2 & Discriminant Validity \\
\hline Monitoring $\leftrightarrow$ & .72 & \multirow{2}{*}{.58} & \multirow{2}{*}{.34} & \multirow{2}{*}{$\mathrm{O}$} \\
\hline Knowledge sharing & .71 & & & \\
\hline Monitoring $\leftrightarrow$ & .72 & \multirow{2}{*}{.58} & \multirow{2}{*}{.34} & \multirow{2}{*}{$\mathrm{O}$} \\
\hline Information sharing & .61 & & & \\
\hline Monitoring $\leftrightarrow$ & .72 & \multirow{2}{*}{.53} & \multirow{2}{*}{.28} & \multirow{2}{*}{$\mathrm{O}$} \\
\hline Performance & .80 & & & \\
\hline Knowledge sharing $\leftrightarrow$ & .71 & \multirow{2}{*}{.48} & \multirow{2}{*}{.23} & \multirow{2}{*}{$\mathrm{O}$} \\
\hline Information sharing & .61 & & & \\
\hline Knowledge sharing $\leftrightarrow$ & .71 & \multirow{2}{*}{.14} & \multirow{2}{*}{.02} & \multirow{2}{*}{$\mathrm{O}$} \\
\hline Performance & .80 & & & \\
\hline Information sharing $\leftrightarrow$ & .61 & \multirow{2}{*}{.58} & \multirow{2}{*}{.34} & \multirow{2}{*}{$\mathrm{O}$} \\
\hline Performance & .80 & & & \\
\hline
\end{tabular}

\section{Hypotheses Testing}

We tested our research hypotheses by investigating the effects of three variables (monitoring, knowledge sharing, information sharing) on performance. To test the hypotheses, structural equation modeling (SEM), AMOS 18, was used.

The values of the structural models show that the normed $\chi^{2}$ is 1.18 , less than the desired cutoff value of 3.0 (Cai et al., 2007). The fit indices, GFI and AGFI, are slightly lower than the desred value of 0.9 but they are still satisfactory because they are very close to the threshold. RMR and RMSEA are 0.037 and 0.043 respectively, which indicates the good fit of the model.

H1 posits that monitoring the performance of sub-suppliers by the manufacturer will influence the performance of prime supplier. As expected, there is a positive relationship between two variables and it is statistically satisfied. H1 is supported.

H2 posits that when manufacturer shares knowledge, such as technological skill, with sub-supplier, it will increase the performance of prime suppliers. Contrast to the expectation, it is found to have negative relationship between these two variables. The negative path coefficient is statistically satisfied but $\mathrm{H} 2$ is not supported.

H3 posits that when manufacturer shares information that can be helpful with sub-supplier, it will increase the performance of prime suppliers. As expected, there is a positive relationship between these two variables and it is statistically satisfied. H3 is support. All the results are presented in Table 4.

Table 4. Results of Main Effects

\begin{tabular}{l|c|c|c}
\hline \multicolumn{1}{c|}{ Constructs } & Supplier Performance & Coefficients & t-value \\
\hline Monitoring & H1 supported & .45 & $3.46^{* * *}$ \\
\hline Knowledge Sharing & H2 supported & -.35 & $-3.08^{* *}$ \\
\hline Information Sharing & H3 supported & .49 & $4.00^{* * *}$ \\
\hline
\end{tabular}

Overall ModelFit

$\chi 2=115.8$, d.f. $=98, \chi 2 /$ d.f. $=1.18, \mathrm{p}=.11, \mathrm{GFI}=.881, \mathrm{AGFI}=.835, \mathrm{CFI}=.985, \mathrm{RMR}=.037, \mathrm{RMSEA}=.043$

${ }^{* * *} \mathrm{p}<.00,{ }^{* *} \mathrm{p}<.005$

Notes: Standardized parameter and accompanying t-values are reported 


\section{DISCUSSION AND IMPLICATION}

Prior work of supplier development has documented why firms are engaged in supplier development and its effectiveness. Kotabe et al., (2003) and Levin and Cross (2004), for example, report that buyer's knowledge sharing with supplier may positively affect the supplier's production efficiency which in turn to lower prices and/or higher quality of outputs. However, studies that examined the effectiveness of supplier development have focused on the activities that are involved in contractually bounded direct exchange relationship, say manufacturer-prime supplier relationship. They have not investigated how development efforts made by manufacturer for sub-supplier influence on prime-supplier firm performance. This study tested the extent to which manufacturer's efforts for enhancing subsupplier improve prime supplier firm performance.

The study provides some results and important implications. First, monitoring sub-supplier performance is found have a positive impact on prime supplier. This result provides different perspective on the effectiveness of monitoring or performance evaluation research. Although performance monitoring was found to have no effect on prime supplier performance in prior research, this research found that it is effective when the program is conducted toward subsupplier. This implies that sub-suppliers may still need such approach. Unlike prime supplier, sub-supplier may have insufficient knowledge and funds for building self-evaluation system. In addition, manufacturer can provide broader insight with quality inspection while prime supplier just focus only on inspection. By having opportunities of getting direct feedback from manufacturer, sub-supplier might learn the extent to which final customer, manufacturer, expects performance level in the supply chain.

Second, information sharing with sub-supplier was also found to have positive association with prime supplier performance. When manufacturer shares information that is also given to prime supplier with sub-supplier, information distortion effect can be reduced. The results imply that manufacturer can benefit from investment on indirect transaction partner if the partner has something to do with the manufacturer's prime suppliers. Direct information can increase predictability of sub-supplier to set optimal plans for management such as production/delivery schedule or inventory level management. Therefore, sub-supplier does not need to incur excess raw materials cost due to, for example, unplanned purchases of supplies, additional manufacturing expenses, and additional transportation costs due to inefficient scheduling (Lee et al., 2004). This, then, reduces inefficiencies of sub-supplier and increases performance, which in turn, positively impact on prime supplier firm performance.

One surprising result in this research is that the negative relationship between knowledge sharing and performance. Prior studies (e.g., Kotabe et al., 2000; Dyer and Hatch, 2006; Modi and Mabert, 2007) reveal the positive association between knowledge sharing and supplier performance. However, these studies either distinguish the tier of suppliers or just investigated the dyad relationship except Kotabe et al., (2000). This result is consistent the study of Kotabe and his colleagues who found that knowledge transfer had positive association with only prime suppliers and only in the U.S. sample but neither case in the Japanese sample. However, they did not provide explanation about why only the prime supplier performance was improved but only explained why technical exchange was not effective in the Japanese sample. Simply, Kotabe and the colleagues focused the difference between two countries. Therefore, it is needed to be explained why knowledge sharing with sub-supplier does not have positive impact and even negative impact.

One possible reason is that the difference between knowledge sharing and other activities. While monitoring and information sharing is relatively easily implemented, knowledge sharing is the activity that takes time. For example, know-how is the "accumulated" practical skill, which implies that it must be learned and acquired (Kogut and Zander). Learning and acquiring certain skill is definitely time-consuming process, therefore immediate pay-off from knowledge sharing may be elusive (Kotabe et al., 2003). In contrast, monitoring and information sharing can extract positive results relatively quickly. However, this explanation is not enough to explain the negative relationship between knowledge sharing and performance even taking the indirect relationship between manufacture and subsupplier into account.

\section{AUTHOR INFORMATION}

Minhye Park, Sungkyunkwan University, South Korea. E-mail: muzzy623@skku.edu (corresponding author) 


\section{REFERENCES}

Argote, L., Beckman, S. L., \& Epple, D. (1990). The persistence and transfer of learning in industrial settings. Management Science, 36(2), 140-154.

Argote, L., Ingram, P., Levine, J. M., \& Moreland, R. L. (2000). Knowledge transfer in organizations: Learning from the experience of others. Organizational behavior and human decision processes, 82(1), 1-8.

Arroyo-López, P., Holmen, E., \& De Boer, L. (2012). How do supplier development programs affect suppliers? Insights for suppliers, buyers and governments from an empirical study in Mexico. Business Process Management Journal, 18(4), 680-707.

Azadegan, A. (2011). Benefiting from supplier operational innovativeness: The influence of supplier evaluations and absorptive capacity. Journal of Supply Chain Management, 47(2), 49-64.

Baum, J. A., \& Ingram, P. (1998). Survival-enhancing learning in the Manhattan hotel industry, 1898-1980. Management Science, 44(7), 996-1016.

Cai, S., Goh, M., de Souza, R., \& Li, G. (2013). Knowledge sharing in collaborative supply chains: Twin effects of trust and power. International Journal of Production Research, 51(7), 2060-2076.

Calantone, R., \& Dröge, C. (1999). Supply chain flexibility: an empirical study. Journal of Supply Chain Management, 35(2), 1624.

Chao, L. Areddy, J., \& Poon, A., (2012). Apple agreement to ripple across China. Wall Street Journal, (2, April).

Cheng, J. H., Yeh, C. H., \& Tu, C. W. (2008). Trust and knowledge sharing in green supply chains. Supply Chain Management: An International Journal, 13(4), 283-295.

Daft, R. L., Lengel, R. H., \& Trevino, L. K. (1987). Message equivocality, media selection, and manager performance: Implications for information systems. MIS quarterly, 355-366.

Dahlstrom, R., \& Nygaard, A. (1999). An empirical investigation of ex post transaction costs in franchised distribution channels. Journal of marketing Research, 160-170.

Darr, E. D., \& Kurtzberg, T. R. (2000). An investigation of partner similarity dimensions on knowledge transfer. Organizational behavior and human decision processes, 82(1), 28-44.

De Meyer, A., Nakane, J., Miller, J. G., \& Ferdows, K. (1989). Flexibility: the next competitive battle the manufacturing futures survey. Strategic Management Journal, 10(2), 135-144.

De Toni, A., \& Nassimbeni, G. (2000). Just-in-time purchasing: an empirical study of operational practices, supplier development and performance. Omega, 28(6), 631-651.

Dyer, J. H., \& Nobeoka, K. (2000). Creating and managing a high-performance knowledge-sharing network: the Toyota case. Strategic management journal, 21(3), 345-367.

Dyer, J. H., \& Hatch, N. W. (2006). Relation-specific capabilities and barriers to knowledge transfers: creating advantage through network relationships. Strategic management journal, 27(8), 701-719.

El Akremi, A., Mignonac, K., \& Perrigot, R. (2011). Opportunistic behaviors in franchise chains: The role of cohesion among franchisees. Strategic Management Journal, 32(9), 930-948.

Erdogan, B., \& Enders, J. (2007). Support from the top: supervisors' perceived organizational support as a moderator of leadermember exchange to satisfaction and performance relationships. Journal of applied psychology, 92(2), 321.

Fawcett, S. E., Osterhaus, P., Magnan, G. M., Brau, J. C., \& McCarter, M. W. (2007). Information sharing and supply chain performance: the role of connectivity and willingness. Supply Chain Management: An International Journal, 12(5), 358-368.

Flynn, B. B., Sakakibara, S., \& Schroeder, R. G. (1995). Relationship between JIT and TQM: practices and performance. Academy of management Journal, 38(5), 1325-1360.

FKILSC (Federation of Korean Industries Large and Small business Cooperation) (2014). The current support for suppliers of major corporations.

Fornell, C., \& Larcker, D. F. (1981). Structural equation models with unobservable variables and measurement error: Algebra and statistics. Journal of marketing research, 382-388.

Forrester, J. (1961). W.(1961). Industrial Dynamics. in Lee, H. L., Padmanabhan, V., \& Whang, S. (2004). Information distortion in a supply chain: The bullwhip effect. Management science, 50(12_supplement), 1875-1886.

Frankel, R., Goldsby, T. J., \& Whipple, J. M. (2002). Grocery industry collaboration in the wake of ECR. The International Journal of Logistics Management, 13(1), 57-72.

Gassenheimer, J. B., Baucus, D. B., \& Baucus, M. S. (1996). Cooperative arrangements among entrepreneurs: An analysis of opportunism and communication in franchise structures. Journal of Business Research, 36(1), 67-79.

Gerwin, D. (1993). Manufacturing flexibility: a strategic perspective. Management science, 39(4), 395-410.

Ghosh, M., \& John, G. (1999). Governance value analysis and marketing strategy. The Journal of Marketing, 131-145.

Glazer, R. (1991). Marketing in an information-intensive environment: strategic implications of knowledge as an asset. The Journal of Marketing, 1-19.

Goffman, E. (1970). Strategic interaction (Vol. 1). University of Pennsylvania Press. in Oliver, W. (1975). Markets and hierarchies: Analysis and antitrust implications.

Gouldner, A. W. (1960). The norm of reciprocity: A preliminary statement. American sociological review, 161-178. 
Grant, R. M. (1996). Toward a knowledge-based theory of the firm. Strategic management journal, 17(S2), 109-122.

Heide, J. B., Wathne, K. H., \& Rokkan, A. I. (2007). Interfirm monitoring, social contracts, and relationship outcomes. Journal of marketing Research, 44(3), 425-433.

Heide, J. B., \& Miner, A. S. (1992). The shadow of the future: Effects of anticipated interaction and frequency of contact on buyer-seller cooperation. Academy of management journal, 35(2), 265-291.

Hill, C. W., \& Rothaermel, F. T. (2003). The performance of incumbent firms in the face of radical technological innovation. Academy of Management Review, 28(2), 257-274.

Hur, Y., Moriuchi, E., Ackerman, D., Rhee, J. (2014). Inter-Organizational Power and Control Mechanisms: The Role of Benevolence and Credibility. Journal of Marketing Thought, 1(2), 49-57.

Hur, Y., Nam, S., \& Carvalho, S. W. (2014). The Mediating Effect of Trust and Value on Loyalty. Journal of Marketing Thought, 1(2), 48-58.

Hwang, K. M., \& Lee, S. J., (2016). How Does Electronic Data Interchange(EDI) affect the Competitiveness of a Firm's Supply Chain Management?. Journal of Marketing Thought, 3(2), 13-18.

Jang, W. (2014). The Kind of Knowledge that makes Network Stronger. Journal of Marketing Thought, 1(3), 23-31

Jeon, E., \& Ha, J., (2016). How Interfirm Relationship Depend on Communication : The Moderating Role of Collaborative Communication in Regional Clusters. Journal of Marketing Thought, 2(4), 29-34.

Jun, S., Kabadayi, S., \& Ryu, S. (2014). Evolution of Trust in Exchange Relationship. Journal of Marketing Thought, 1(3), 1122.

Kang, H., Min, J., \& Lee, J. (2016). The Effects of Uncertainties on Network Embeddedness and the Mediating Effect of Information Sharing. Journal of Marketing Thought, 2(4), 1-14.

Kang, H., \& Smith, S., (2016), Effect of Uncertainties on Network Embeddedness and the Moderating Role of Information Sharing. Journal of Marketing Thought, 3(2), 19-30.

Kasheer, M. (2015). Antecedents and Outcomes of Trust: Role of Communication Intensity and Goal Alignment in Building Long Term Business Relationships. Journal of Marketing Thought, 2(3), 13-19.

Kapoor, R., \& Lee, J. M. (2013). Coordinating and competing in ecosystems: How organizational forms shape new technology investments. Strategic Management Journal, 34(3), 274-296.

Kim, J., \& Lee, J. (2016). The Moderating Effect of Ethical Leadership on Relationship between Monitoring Activity and Opportunism. Journal of Marketing Thought, 2(4), 40-46.

Kim, K., Sung, M., \& Jung, G. O. (2015). Revisiting TSI: How TSI Contributes to the Buyer-Seller Relationship. Journal of Marketing Thought, 1(4), 10-21

Kim, S. D., (2015). Bureaucratic Structuring, Transaction Specific Investment, and Relationship Quality: Moderating Roles of Information Exchange between Manufacturer and Distributor. Journal of Marketing Thought, 2(1), 1-13.

Kogut, B., \& Zander, U. (1992). Knowledge of the firm, combinative capabilities, and the replication of technology. Organization science, 3(3), 383-397.

Ko, H., \& Smith, S. (2016). How Manufacturer Satisfaction with Supplier Performance is Influenced by Upstream and Horizontal Relationships: Solidarity, and Conflict. Journal of Marketing Thought, 3(1), 33-43

Kotabe, M., Martin, X., \& Domoto, H. (2003). Gaining from vertical partnerships: knowledge transfer, relationship duration, and supplier performance improvement in the US and Japanese automotive industries. Strategic management journal, 24(4), 293-316.

Krause, D. R. (1999). The antecedents of buying firms' efforts to improve suppliers. Journal of operations management, 17(2), 205-224.

Krause, D. R., Scannell, T. V., \& Calantone, R. J. (2000). A structural analysis of the effectiveness of buying firms' strategies to improve supplier performance. Decision Sciences, 31(1), 33-55.

Kydd, C. T. (1989). Understanding the information content in MIS management tools. MIS Quarterly, 277-290.

Lee, H. L., Padmanabhan, V., \& Whang, S. (2004). Information distortion in a supply chain: The bullwhip effect. Management science, 50(12_supplement), 1875-1886.

Lee, K. W., Ha, J. \& Kim, H. (2014). Complementary Effects of Marketing Network and Structure holes on Supplier's Perceived New Product Development Performance of Buyer: Moderating Effect of Technological Uncertainty. Journal of Marketing Thought, 1(1), 50-58.

Levin, D. Z., \& Cross, R. (2004). The strength of weak ties you can trust: The mediating role of trust in effective knowledge transfer. Management science, 50(11), 1477-1490.

Lim, Y., Smith, S., \& Kim, E. (2014). The Relationship between Environmental Uncertainty and Opportunism in Marketing Channels: The Moderating Effect of Network Embeddedness. Journal of Marketing Thought, 1(1), 22-42.

Lucas, L. (2012). Starbucks assists fund for developing world farmers. FinancialTimes, (23April)

Malhotra, A., Gosain, S., \& Sawy, O. A. E. (2005). Absorptive capacity configurations in supply chains: gearing for partnerenabled market knowledge creation. MIS quarterly, 145-187.

Mena, C., Humphries, A., \& Choi, T. Y. (2013). Toward a Theory of Multi-Tier Supply Chain Management. Journal of Supply Chain Management, 49(2), 58-77.

Min, J., Kwak, K., \& Lee, J. (2015). Environmental Uncertainty and Interfirm Controls: The Moderating Effect of Honesty. Journal of Marketing Thought, 1(4), 22-28. 
Min, S., Roath, A. S., Daugherty, P. J., Genchev, S. E., Chen, H., Arndt, A. D., \& Glenn Richey, R. (2005). Supply chain collaboration: what's happening?. The international journal of logistics management, 16(2), 237-256.

Mishra, B. K., Raghunathan, S., \& Yue, X. (2007). Information sharing in supply chains: Incentives for information distortion. IIE Transactions, 39(9), 863-877.

Modi, S. B., \& Mabert, V. A. (2007). Supplier development: Improving supplier performance through knowledge transfer. Journal of operations management, 25(1), 42-64.

Nam, J, Smith, S., \& Kwon, M (2015). The Role of Ties and Structural Holes in the Buyer's Performance across Vertical Marketing Channel Systems: A Triadic Perspective. Journal of Marketing Thought, 1(4), 72-77.

Nayyar, P. R. (1990). Information asymmetries: A source of competitive advantage for diversified service firms. Strategic Management Journal, 11(7), 513-519.

Nunlee, M. P. (2005). The control of intra-channel opportunism through the use of inter-channel communication. Industrial Marketing Management, 34(5), 515-525.

Oliver, W. (1975). Markets and hierarchies: Analysis and antitrust implications.

Owyong, D. T. (2000). Measuring the trickle-down effect: a case study on Singapore. Applied Economics Letters, 7(8), 535-539.

Parkhe, A. (1993). Strategic alliance structuring: A game theoretic and transaction cost examination of interfirm cooperation. Academy of management journal, 36(4), 794-829.

Pfeffer, J., \& Salancik, G. R. (2003). The external control of organizations: A resource dependence perspective. Stanford University Press.

Rhee, M. K., \& Cho, N. (2016). A Study on Factors Influencing Network Performances: A Moderating Role of Dependence. Journal of Marketing Thought, 2(4), 35-39.

Rogers, P. P., Ojha, D., \& White, R. E. (2011). Conceptualising complementarities in manufacturing flexibility: a comprehensive view. International journal of production research, 49(12), 3767-3793.

Routroy, S., \& Pradhan, S. K. (2013). Evaluating the critical success factors of supplier development: a case study. Benchmarking: An International Journal, 20(3), 322-341.

Ryu, S., \& Eyuboglu, N. (2007). The environment and its impact on satisfaction with supplier performance: An investigation of the mediating effects of control mechanisms from the perspective of the manufacturer in the USA. Industrial Marketing Management, 36(4), 458-469.

Ryu, S., Hung, K., \& Mana, J. (2014). Control Mechanisms for Protecting the Benevolent Partner in the Relationship between Marketing Channel Members. Journal of Marketing Thought, 1(1), 43-49.

Soosay, C. A., Hyland, P. W., \& Ferrer, M. (2008). Supply chain collaboration: capabilities for continuous innovation. Supply Chain Management: An International Journal, 13(2), 160-169.

Sterman, J. D. (1989). Modeling managerial behavior: Misperceptions of feedback in a dynamic decision making experiment. Management science, 35(3), 321-339. in Lee, H. L., Padmanabhan, V., \& Whang, S. (2004). Information distortion in a supply chain: The bullwhip effect. Management science, 50(12_supplement), 1875-1886.

Stump, R. L., \& Heide, J. B. (1996). Controlling supplier opportunism in industrial relationships. Journal of Marketing Research, 431-441.

Swamidass, P. M., \& Newell, W. T. (1987). Manufacturing strategy, environmental uncertainty and performance: a path analytic model. Management science, 33(4), 509-524.

Rao Tummala, V. M., Phillips, C. L., \& Johnson, M. (2006). Assessing supply chain management success factors: a case study. Supply Chain Management: An International Journal, 11(2), 179-192.

Von Hippel, E. (2007). The sources of innovation (pp. 111-120). Gabler.

Wagner, S. M., (2006). Supplier development practices: an exploratory study. European journal of marketing, 40(5/6), 554-571.

Wang, Z. (2015). The Antecedents and Impact of Network Capabilities on Innovation Performance. Journal of Marketing Thought, 2(3), 41-50.

Watts, C. A., \& Hahn, C. K. (1993). Supplier development programs: an empirical analysis. International Journal of Purchasing and Materials Management, 29(1), 10-17.

Williamson, O. E. (1996). The mechanisms of governance. Oxford University Press.

Yi, C. Y., Ngai, E. W. T., \& Moon, K. L. (2011). Supply chain flexibility in an uncertain environment: exploratory findings from five case studies. Supply Chain Management: An International Journal, 16(4), 271-283.

Zhou, K. Z., \& Li, C. B. (2012). How knowledge affects radical innovation: Knowledge base, market knowledge acquisition, and internal knowledge sharing. Strategic Management Journal, 33(9), 1090-1102. 